Background: Recurrence of hepatitis $C$ after liver transplantation is an almost universal occurrence. T-cell derived cytokines have an important role in the development of liver damage associated with chronic hepatitis $C$, their post-transplant levels, however, have not been correlated with histologic recurrence of the disease.

Aims: We sought to analyze levels of TNF- $\alpha$, soluble IL2 receptor, IL- 4 and IL-10 at 1 month, 6 months and 1 year after transplantation in 27 patients undergoing transplantation for hepatitis $\mathrm{C}$ related end-stage liver disease.

Metbods: HCV RNA levels were monitored by a branched-chain DNA signal amplification assay. Diagnosis of recurrent hepatitis was based on 1-year protocol biopsies and on biopsies performed for liver enzyme elevations.

Results: Recurrent hepatitis C was detected in 52\% $(n=14)$ of the 27 patients. HCV RNA levels rose over time in all patients regardless of histologic recurrence. TNF- $\alpha$, and IL- 4 levels, although elevated, did not show specific patterns over time or in correlation with recurrence. Similarly, the early elevation followed by a gradual decrease over the first year in the amount of soluble IL-2 receptor was not related to histologic recurrence. We observed a significant increase in circulating IL-10 levels over the first year in patients with biopsy-proven recurrence, while patients with no signs of histologic recurrence displayed increased, but steady levels.

Conclusions: These results suggest that while these cytokines are associated with post-transplant recurrence of hepatitis $C$, their production may be altered by additional factors.

Key words: Liver transplantation, Hepatitis C, Recurrence, Cytokines

\section{Recurrence of hepatitis $C$ after liver transplantation is associated with increased systemic IL-10 levels}

\author{
Patricia A. Sheiner, Sander S. Florman, Sukru Emre, \\ Thomas Fishbein, Myron E. Schwartz, \\ Charles M. Miller and Peter Boros ${ }^{\mathrm{CA}}$
}

The Recanati Miller Transplantation Institute, Mount Sinai School of Medicine, One Gustave L. Levy Place, POB 1504, New York, NY 10029, USA

${ }^{\mathrm{CA}}$ Corresponding Author
Tel: +1 2122415589
Fax: +1 2124262233
E-mail: Peter.Boros@MSSM.EDU

\section{Introduction}

Hepatitis $C$ is a progressive disease that leads to cirrhosis in approximately $20 \%$ of affected individuals ${ }^{1-3}$ and has emerged as the most common indication for liver transplantation in both Europe and the USA. ${ }^{4}$ Serologic recurrence of hepatitis $\mathrm{C}$ infection after transplantation is virtually universal. ${ }^{5,6}$ Histologic recurrence has been observed in 30-70\% of patients within one year following transplantation for hepatitis $C$ related end-stage liver disease. ${ }^{6-8} \mathrm{~A}$ subset of these patients will develop allograft failure as a result of hepatitis $C$ recurrence requiring retransplantation. ${ }^{9}$

The nature of the injury induced by chronic hepatitis $\mathrm{C}$ infection has been extensively investigated. Cytokines appear to play an important role in the liver damage associated with chronic hepatitis $\mathrm{C}$ via a variety of mechanisms, including activation of $T$ lymphocytes, ${ }^{10}$ direct hepatocellular damage, ${ }^{11}$ and by modulation of both the viral-specific immune response $\mathrm{e}^{12,13}$ and viral replication. ${ }^{14,15}$ The relation between changes in cytokine patterns and posttransplant recurrence of hepatitis $\mathrm{C}$, however, is unclear.

This study was designed to evaluate cytokine profiles (TNF- $\alpha$, IL- 4 , IL-10, and the soluble receptor of IL-2 [sIL-2R]) over the first year following primary orthotopic liver transplantation (OLTx) for liver failure secondary to hepatitis $\mathrm{C}$ and to correlate these profiles with hepatitis C RNA viral levels and with biopsy-proven histologic recurrence.

\section{Patients and methods}

Patients

Twenty-seven patients transplanted for liver failure secondary to hepatitis C cirrhosis between February 1994 and December 1996 were included in this study. 


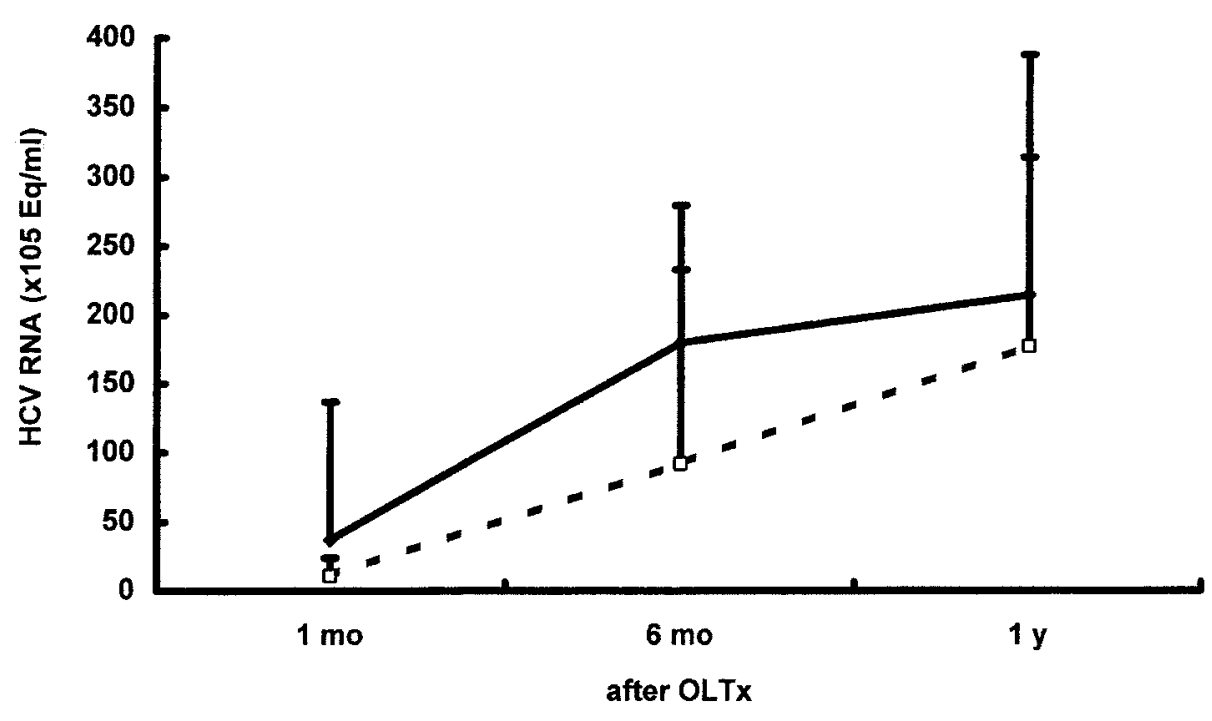

- Recurrence $=$ a- No Recurrence

FIG. 1. HCV RNA levels in patients transplanted for hepatitis $C$ related liver failure.

Patients undergoing transplantation for hepatitis C with hepatocellular carcinomas requiring adjuvant chemotherapy (i.e., tumors $>3 \mathrm{~cm}$ or with vascular invasion), or with positive serology for hepatitis $B$ surface antigen were excluded. Informed consent was obtained from all patients prior to enrollment.

\section{OLTX}

All patients received induction immunotherapy with OKT3 followed by triple immunosuppression therapy with cyclosporine, azathioprine and steroids. Patients were converted to tacrolimus for recurrent or severe rejection episodes or for side effects of cyclosporine.

\section{Sample collection}

Serum samples were obtained from each patient preoperatively and at 1 month, 6 months and 1 year after transplantation. All samples were aliquoted into cryotubes and stored at $-80^{\circ} \mathrm{C}$ until analyzed.

\section{Hepatitis C virus RNA levels}

RNA levels were determined in duplicate by a branched-chain DNA signal amplification assay (Chiron HCV RNA 1.0, Chiron Diagnostics, Emeryville, CA). Actual hepatitis $\mathrm{C}$ viral concentrations were computed for each sample using a standard curve provided by the manufacturer.

\section{Cytokine levels}

Serum cytokines were measured using commercially available ELISA kits for IL-10, IL-4, sIL-2R and TNF- $\alpha$ (Immunotech, France) following the manufacturer's instructions. Actual cytokine levels were calculated for each cytokine using a specific standard curve supplied by the manufacturer. According to the manufacturer, there are no detectable levels of these cytokines in normal human sera.

\section{Diagnosis of recurrence}

The diagnosis of recurrent hepatitis was made histologically by examination of 1-year protocol biopsies and/or examination of biopsies performed for liver enzyme elevations. Histologic diagnosis was based on the presence of: (1) diffuse necroinflammatory lesions within the parenchyma in the absence of acute cellular rejection and other causes of acute hepatitis (e.g., CMV, hepatitis B, drugs) along with dense lymphoid aggregates and lymphoid follicles in the portal tracts, or (2) piecemeal necrosis and bridging necrosis in the absence of other causes.

\section{Statistical analysis}

All data were expressed as the mean \pm SD. Data were analyzed with ANOVA. Only $p$ values $<0.05$ following Bonferroni correction were considered statistically significant.

\section{Results}

\section{Recurrent hepatitis}

Biopsy-proven histologic evidence of hepatitis recurrence was evident in $52 \%(n=14)$ of the 27 patients.

\section{Hepatitis C viral RNA levels}

Serum levels of hepatitis $\mathrm{C}$ viral RNA are shown in Fig. 1. All patients had evidence of hepatitis $C$ viremia after transplantation, regardless of evidence of histologic recurrence of hepatitis. Over the first year 
Table 1. Serum cytokine levels in patients transplanted for hepatitis $C$ related liver failure

\begin{tabular}{|c|c|c|c|c|c|c|}
\hline & \multicolumn{6}{|c|}{ After OLT $\times$ in patients } \\
\hline & \multicolumn{2}{|c|}{1 month } & \multicolumn{2}{|c|}{6 months } & \multicolumn{2}{|c|}{1 year } \\
\hline & Recurrence & No recurrence & Recurrence & No recurrence & Recurrence & No recurrence \\
\hline TNF- $\alpha(\mathrm{pg} / \mathrm{ml})$ & $300 \pm 144$ & $324 \pm 1136$ & $312 \pm 1115$ & $351 \pm 1151$ & $315 \pm 1122$ & $341 \pm 1139$ \\
\hline sIL-2R (pg/ml) & $102 \pm 197$ & $91 \pm 1123$ & $68 \pm 151$ & $65 \pm 166$ & $58 \pm 155$ & $57 \pm 161$ \\
\hline IL-4 (pg/ml) & $199 \pm 1195$ & $331 \pm 1329$ & $267 \pm 1165$ & $286 \pm 1233$ & $250 \pm 1290$ & $315 \pm 1317$ \\
\hline
\end{tabular}

following transplantation, viral RNA levels rose significantly in patients with and without recurrence. No significant differences in viral levels were observed between the two patient groups at any time point.

TNF- $\alpha$ levels

Serum levels of TNF- $\alpha$ were considerably elevated following transplantation and remained elevated over the first year in both patient groups. No significant differences were observed over time in either group or between the 2 patient groups (Table 1 ).

\section{sIL-2R levels}

A moderate elevation in levels of sIL-2R was observed in both patient groups at 1 month following transplantation. In both groups, there was a decreasing trend over the first year regardless of histologic recurrence, with no differences between the 2 patient groups (Table 1 ).

\section{IL-4 levels}

No significant differences in IL-4 levels were observed over time in either group or between the 2 patient groups (Table 1).

\section{IL-10 levels}

Changes in serum levels of IL-10 are shown in Fig. 2. In patients without histologic evidence of recurrence, levels of IL-10 were elevated after transplantation but did not vary significantly over the first year. On the other hand, in patients with histologic evidence of recurrence, IL-10 levels dramatically increased over time, with a statistically significant difference between 1 month and 1 year $(p<0.01)$, as well as between 6 months and 1 year $(p<0.01)$. Additionally, there was a considerably significant difference between IL-10 levels in the 2 patient groups at 1 year $(p<0.05)$.

\section{Discussion}

The immunologic mechanisms involved in chronic hepatitis C-related liver injury are not fully understood, and these events may be even more complex in recurrent hepatitis $\mathrm{C}$ following transplantation. Intense immunosuppression, ${ }^{16,17}$ pre-transplantation viral load, post-transplantation changes in viral level, ${ }^{9,18}$ and the viral genotype ${ }^{19}$ have all been postulated to affect hepatitis $\mathrm{C}$ recurrence following liver transplantation.

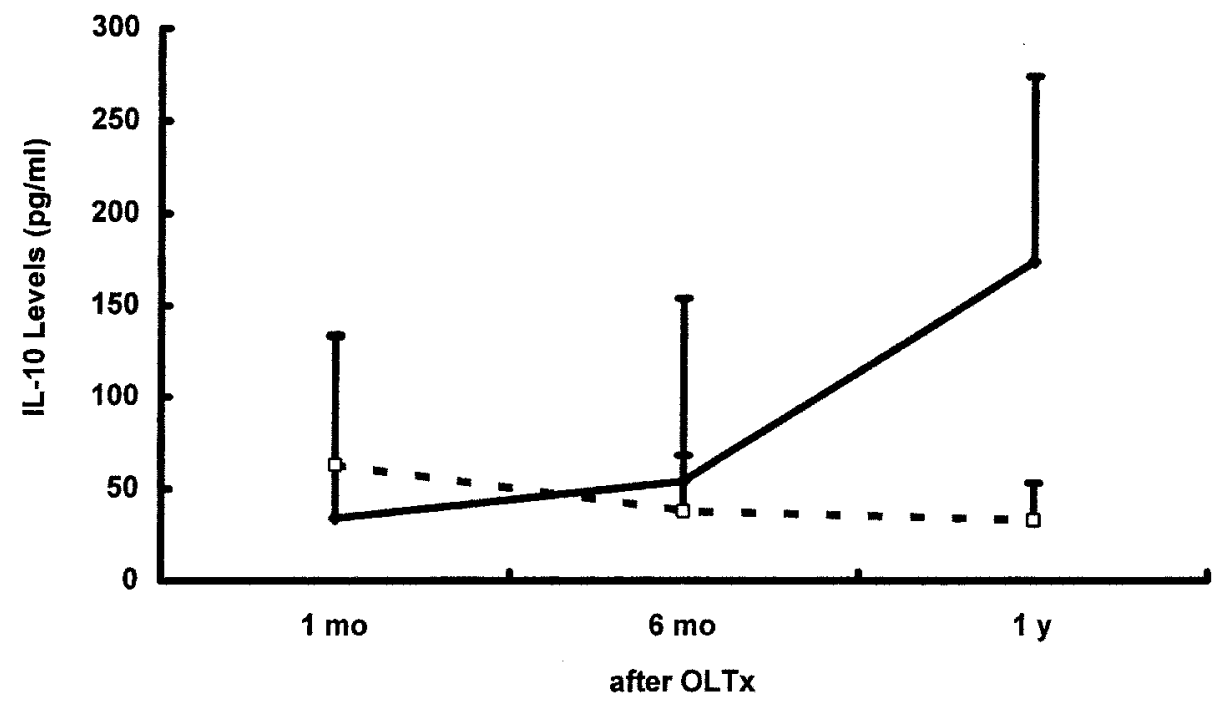

FIG. 2. IL-10 levels in patients transplanted for hepatitis $C$ related liver failure. 
In the present study, we observed that in patients who undergo liver transplantation for hepatitis C infection, viral levels rise over the first year regardless of histologic recurrence. Furthermore, the quantity of circulating virus did not correlate with the finding of histologic recurrence. These observations support those of previous studies, which have found that viremia develops in almost all patients after liver transplantation for hepatitis $\mathrm{C}$ and that the severity of recurrent hepatitis $\mathrm{C}$ does not correlate with viral levels. ${ }^{11,20,21}$

Cytokines are crucial mediators of tissue homeostasis. As important co-stimulators of T-cell activation, cytokines function to broaden the allograft immune response by recruiting other cells and stimulating the expression of adhesion molecules. In chronic liver diseases, cytokine profiles are known to vary according to the specific etiology as well as disease severity. ${ }^{22-24}$ The T-helper type 1 (Th-1)/T-helper type 2 (Th-2) paradigm is based upon distinct cytokine secretion patterns from 2 sub-populations of CD4+ T-helper lymphocytes. ${ }^{25,26}$ Th- 1 cells are involved in cellular immunity, and Th1 related cytokines (IL-2, TNF- $\alpha$, IFN- $\gamma$ ) are important in the host antiviral immune response. Th-2 cells are central to humoral immunity, while Th-2 related cytokines (IL-4, IL-10) have major negative immunoregulatory functions. A shift in Th-1/Th-2 balance might be involved in disease progression. ${ }^{10,22,26,27}$

The cytokines chosen for evaluation in this study all play important roles in humoral and cell-mediated immunity, as they represent both the Th-1 (sIL-2R, TNF- $\alpha$ ) and Th-2 (IL-4, IL-10) arms of T-cell response. Since all these cytokines are known to be elevated in chronic hepatitis $\mathrm{C}$, monitoring their levels following transplantation offers a unique opportunity to investigate their possible association with recurrent hepatitis $\mathrm{C}$. The increased levels of these mediators following OLTx in patients with liver failure secondary to hepatitis $C$ represent an activated $T$ lymphocyte response.

In patients with chronic hepatitis $\mathrm{C}, \mathrm{TNF}-\alpha$ has been observed to regulate hepatocyte damage and to be present in increased levels.,23,28-31 While we observed significantly elevated levels of TNF- $\alpha$ over the first year following liver transplantation in patients with and without recurrence, there was no correlation between TNF- $\alpha$ levels and histologic recurrence or viral RNA levels.

Increased release of sIL-2R, a marker of $T$ cell activation, has also been reported by several groups in patients with chronic hepatitis. ${ }^{2,15,32-35}$ The moderate increase in sIL-2R levels described in the present study 1 month following liver transplantation was irrespective of outcome and may reflect the effects of the intense immunosuppression on activated $T$ cells. Indeed, earlier we reported that sIL-2R levels increased during the first week after OLTx in patients with hepatitis $\mathrm{C}$, with the highest levels measured in patients whose primary immune suppression was OKT3, likely denoting the marked degree of cytolysis which occurs following OKT3 administration. ${ }^{36}$

IL- 4 is involved in the humoral immune response. Its effects have been observed to be associated with the progression of viral infections, and its production is known to be enhanced in patients with chronic hepatitis C. ${ }^{10,12,22}$ Increased expression of IL- 4 has been linked to the development of hepatitis C chronicity. ${ }^{37}$ In this study, we observed significantly elevated levels of IL-4 that were sustained over the first year following transplantation, but we saw no specific patterns that correlated with histologic recurrence or viral load.

IL-10 is known to inhibit many effector functions of the immune system. ${ }^{12,13,38}$ Its production has also been observed to be significantly enhanced in patients with chronic active hepatitis C. ${ }^{10,39}$ We found increased levels of IL-10 in both patient groups following transplantation. An immediate/ early post-transplantation increase in systemic IL-10 levels, which quickly returned to normal values, has been reported and was associated with possible activation of the graft's macrophages. ${ }^{40}$ The changes in the post-transplant pattern of systemic IL-10 levels reported here for the first time - a dramatic increase over the first year only in those patients with histologic evidence of recurrence support that IL-10 may be related to the development of hepatitis C chronicity. ${ }^{37}$ Increased levels of IL-10 inhibit the development of Th-1 effector mechanisms, leading to decreased IFN- $\gamma$ production and antiviral response. ${ }^{33}$ While persistent $\mathrm{HCV}$ replication was shown to be associated with the release of IL-10 in other studies, ${ }^{39}$ the fact that in our patients HCV-RNA levels rose over the first year regardless of histological evidence of recurrence suggest a more complex, yet unclear role for IL-10 in post-transplant recurrent hepatitis C.

Our findings indicate that after liver transplantation for hepatitis $\mathrm{C}$, production of these 4 cytokines is not exclusively driven by disease recurrence but may be altered by confounding factors, including graft damage, allo-specific immune response and immunosuppression. While induction immunotherapy was uniformly achieved with OKT3 among these patients, the sampling schedule did not allow us to correlate cytokine levels to important clinical variables such as ischemia/reperfusion damage, frequency and treatment of rejection episodes, or infection. Since these mediators may serve as possible targets for treatment of post-transplant recurrent hepatitis $\mathrm{C}$, further investigations are warranted. 


\section{References}

1. Dienstag JL. Non-A, non-B hepatitis. I. Recognition, epidemiology, and clinical features. Gastroenterology 1983: 85: 439-62.

2. Quiroga JA, Martin J, Pardo M, Carreno V. Serum levels of soluble immune factors and pathogenesis of chronic hepatitis $\mathrm{C}$, and their relation to therapeutic response to interferon-alpha. Dig Dis Sci 1994: 39: 2485-96.

3. Alter MJ, Margolis HS, Krawczynski K, et al. The natural history of community-acquired hepatitis $\mathrm{C}$ in the United States. The Sentinel Counties Chronic non-A, non-B Hepatitis Study Team [see comments]. $N$ Engl J Med 1992: 327: 1899-905.

4. Stratta RJ, Shaefer MS, Cushing KA, et al. A randomized prospective trial of acyclovir and immuneglobulin prophylaxis in liver transplant recipients receiving OKT3 therapy. Arch Surg 1992: 127: 55-63.

5. Wright TL, Donegan E, Hsu HH, et al. Recurrent and acquired hepatitis $\mathrm{C}$ viral infection in liver transplant recipients. Gastroenterology 1992 103: 317-22.

6. Greenson JK, Svoboda-Newman SM, Merion RM, Frank TS. Histologic progression of recurrent hepatitis $\mathrm{C}$ in liver transplant allografts. $A m \mathrm{~J}$ Surg Pathol 1996: 20: 731-8.

7. Konig V, Bauditz J, Lobeck H, et al. Hepatitis C virus reinfection in allografts after orthotopic liver transplantation. Hepatology 1992: 16: 1137-43.

8. Muller H, Otto G, Goeser T, Arnold J, Pfaff E, Theilmann L. Recurrence of hepatitis $\mathrm{C}$ virus infection after orthotopic liver transplantation. Transplantation 1992: 54: 743-5.

9. Gane EJ, Portmann BC, Naoumov NV, et al. Long-term outcome of hepatitis C infection after liver transplantation [see comments]. $N$ EnglJ Med 1996: 334: 815-20.

10. Cacciarelli TV, Martinez OM, Gish RG, Villanueva JC, Krams SM. Immunoregulatory cytokines in chronic hepatitis $C$ virus infection: preand posttreatment with interferon alfa. Hepatology 1996: 24: 6-9.

11. Napoli J, Bishop GA, McGuinness PH, Painter DM, McCaughan GW. Progressive liver injury in chronic hepatitis $\mathrm{C}$ infection correlates with increased intrahepatic expression of Th1-associated cytokines. Hepatology 1996: 24: 759-65.

12. Reiser M, Marousis CG, Nelson DR, et al. Serum interleukin 4 and interleukin 10 levels in patients with chronic hepatitis $\mathrm{C}$ virus infection. J Hepatol 1997: 26: 471-8.

13. Dumoulin FL, Bach A, Leifeld L, et al. Semiquantitative analysis of intrahepatic cytokine mRNAs in chronic hepatitis C. J Infect Dis 1997: 175: $681-5$.

14. Missale G, Ferrari C, Fiaccadori F. Cytokine mediators in acute inflammation and chronic course of viral hepatitis (editorial). Ann Ital Med Int 1995: 10: 14-8.

15. Simsek H, Kadayifci A. Serum interleukin 2 and soluble interleukin 2 receptor in chronic active hepatitis C: effect of interferon therapy. $J$ Int Med Res 1996: 24: 239-45.

16. Singh N, Gayowski T, Ndimbie OK, Nedjar S, Wagener MM, Yu VL. Recurrent hepatitis $\mathrm{C}$ virus hepatitis in liver transplant recipients receiving tacrolimus: association with rejection and increased immunosuppression after transplantation. Surgery 1996: 119: 452-6.

17. Rosen HR, Shackleton CR, Higa L, et al. Use of OKT3 is associated with early and severe recurrence of hepatitis $\mathrm{C}$ after liver transplantation [see comments]. Am J Gastroenterol 1997: 92: 1453-7.

18. Zhou S, Terrault NA, Ferrell L, et al. Severity of liver disease in liver transplantation recipients with hepatitis $\mathrm{C}$ virus infection: relationship to genotype and level of viremia. Hepatology 1996: 24: 1041-6.

19. Feray C, Gigou M, Samuel D, et al. Influence of the genotypes of hepatitis $\mathrm{C}$ virus on the severity of recurrent liver disease after liver transplantation [see comments]. Gastroenterology 1995: 108: 1088-96.

20. Feray C, Samuel D, Thiers V, et al. Reinfection of liver graft by hepatitis C virus after liver transplantation. J Clin Invest 1992: 89: 1361-5.

21. McGuinness PH, Bishop GA, Painter DM, Chan R, McCaughan GW. Intrahepatic hepatitis C RNA levels do not correlate with degree of liver injury in patients with chronic hepatitis C. Hepatology 1996: 23: 676-87.

22. Bertoletti A, D'Elios MM, Boni C, et al. Different cytokine profiles of intraphepatic $\mathrm{T}$ cells in chronic hepatitis $\mathrm{B}$ and hepatitis $\mathrm{C}$ virus infections. Gastroenterology 1997: 112: 193-9.

23. Tilg H, Wilmer A, Vogel W, et al. Serum levels of cytokines in chronic liver diseases. Gastroenterology 1992: 103: 264-74.

24. Boros P, Suehiro T, Curtiss S, et al. Differential contribution of graft and recipient to perioperative TNF-alpha, IL-1 beta, IL-6 and IL-8 levels and correlation with early graft function in clinical liver transplantation. Clin Transplant 1997: 11: 588-92.

25. Mosmann TR, Cherwinski H, Bond MW, Giedlin MA, Coffman RL. Two types of murine helper T cell clone. I. Definition according to profiles of lymphokine activities and secreted proteins. J Immunol 1986: 136: 2348-57.

26. Del Prete G. The concept of type- 1 and type- 2 helper T cells and their cytokines in humans. Int Rev Immunol 1998: 16: 427-55.

27. Romagnani S. Biology of human TH1 and TH2 cells. J Clin Immunol 1995: 15: $121-9$

28. Imagawa DK, Millis JM, Olthoff $\mathrm{KM}$, et al. The role of tumor necrosis factor in allograft rejection. I. Evidence that elevated levels of tumor necrosis factor-alpha predict rejectionfollowing orthotopic liver transplantation. Transplantation 1990: 50: 219-25.

29. Torre D, Zeroli C, Giola M, et al. Serum levels of interleukin-1 alpha, interleukin-1 beta, interleukin-6, and tumor necrosis factor in patients with acute viral hepatitis. Clin Infect Dis 1994: 18: 194-8.

30. Zhang D, Ren H, Jia X, Zhou Y. Serum tumor necrosis factor (TNF) in the pathogenesis of clinical failure of $\mathrm{HCV}$ and/or HBV infection. Chinese Med J 1993: 106: 335-8.

31. Kishihara Y, Hayashi J, Yoshimura E, Yamaji K, Nakashima K, Kashiwagi S. IL-1 beta and TNF-alpha produced by peripheral blood mononuclear cells before and during interferon therapy in patients with chronic hepatitis C. Dig Dis Sci 1996: 41: 315-21.

32. Morishima I, Kumada T, Nakano S, et al. Serum levels of soluble interleukin-2 receptor in chronic hepatitis $C$ treated with interferonalpha. Scand J Gastroenterol 1995: 30: 807-11.

33. Hayashi J, Kishihara Y, Yamaji K, et al. Serum levels of soluble interleukin2 receptors and effects of interferon-alpha for patients with chronic hepatitis C virus. Dig Dis Sci 1995: 40: 1837-41.

34. Alberti A, Chemello L, Fattovich G, et al. Serum levels of soluble interleukin-2 receptors in acute and chronic viral hepatitis [see comments]. Dig Dis Sci 1989: 34: 1559-63.

35. Jirillo E, Greco B, Caradonna L, et al. Evaluation of cellular immune responses and soluble mediators in patients with chronic hepatitis $\mathrm{C}$ virus (cHCV) infection. Immunopharmacol Immunotoxicol 1995: 17: 347-64.

36. Granot E, Tarcsafalvi A, Emre $\mathrm{S}$, et al. $\mathrm{Th}_{1} \mathrm{Th}_{2}$ cytokines and ICAM-1 levels post-liver transplant do not predict rejection. Med Inflamm 2000: 9, 125-30.

37. Tsai SL, Liaw YF, Chen MH, Huang CY, Kuo GC. Detection of type 2-like T-helper cells in hepatitis $\mathrm{C}$ virus infection: implications for hepatitis $\mathrm{C}$ virus chronicity. Hepatology 1997: 25: 449-58.

38. Fiorentino DF, Zlotnik A, Vieira P, et al. IL-10 acts on the antigenpresenting cell to inhibit cytokine production by Th1 cells. $J$ Immunol 1991: 146: 3444-51

39. Kuzushita N, Hayashi N, Katayama $\mathrm{K}$, et al. High levels of serum interleukin-10 are associated with a poor response to interferon treatment in patients with chronic hepatitis C. Scand J Gastroenterol 1997: 32: 169-74.

40. Le Moine O, Marchant A, Durand F, et al. Systemic release of IL-10 during orthotopic liver transplantation. Hepatology 1994: 20: 889-92.

\section{Received 19 Dec 2000; accepted 5 Jan 2001}




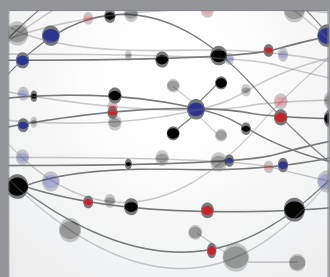

The Scientific World Journal
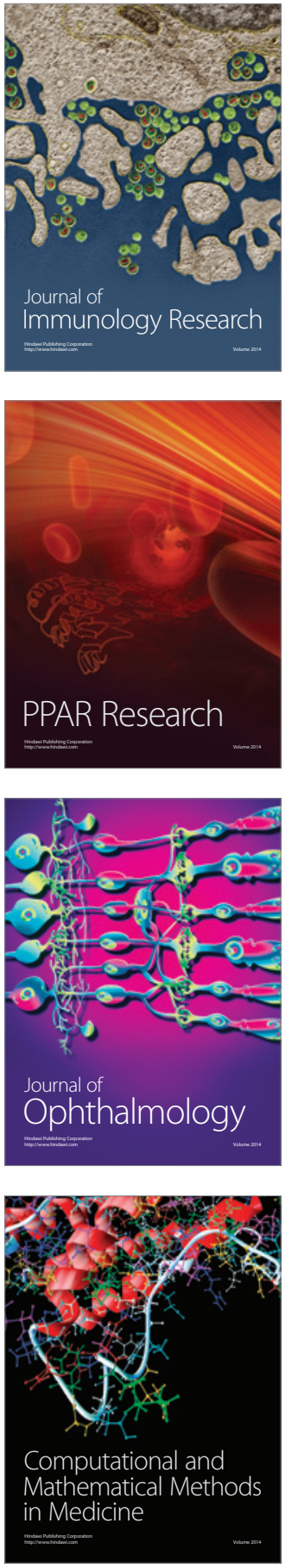

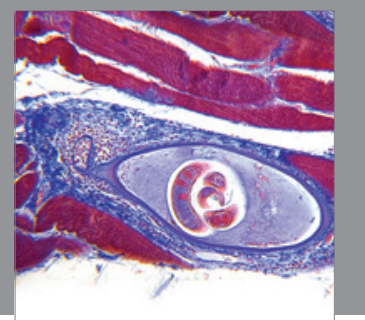

Gastroenterology

Research and Practice
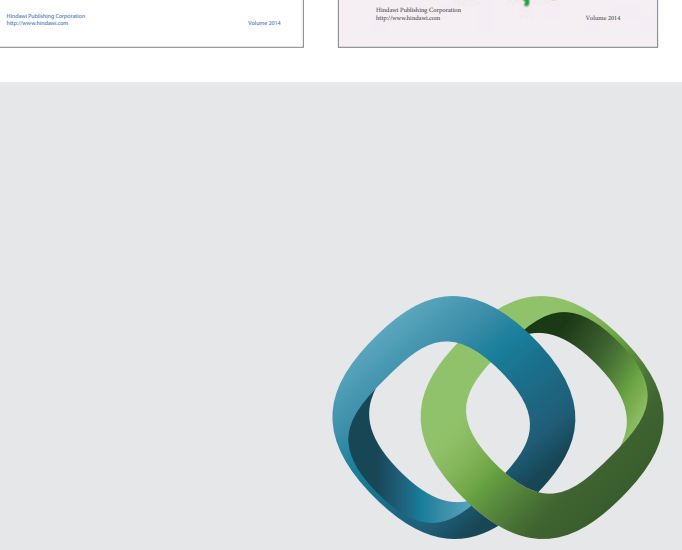

\section{Hindawi}

Submit your manuscripts at

http://www.hindawi.com
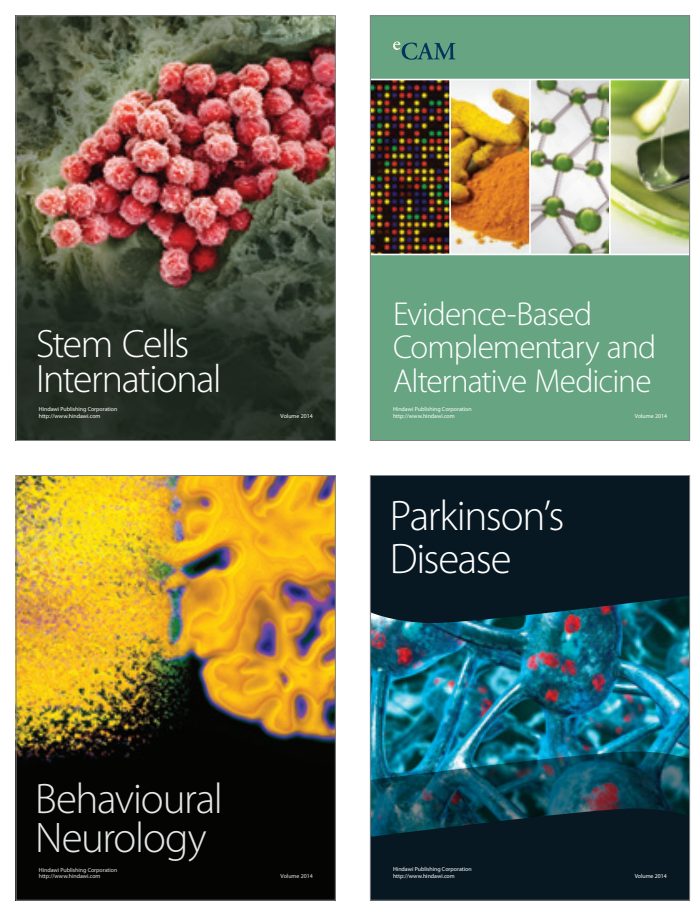

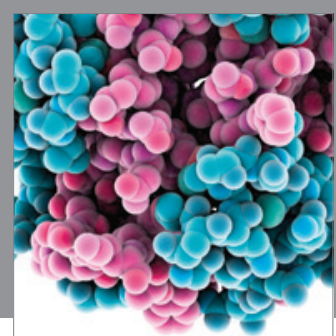

Journal of
Diabetes Research

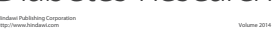

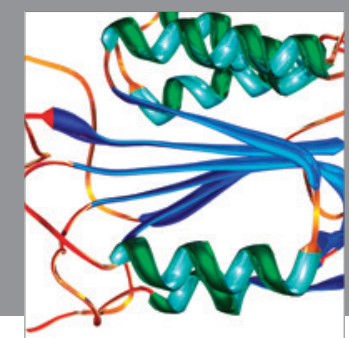

Disease Markers
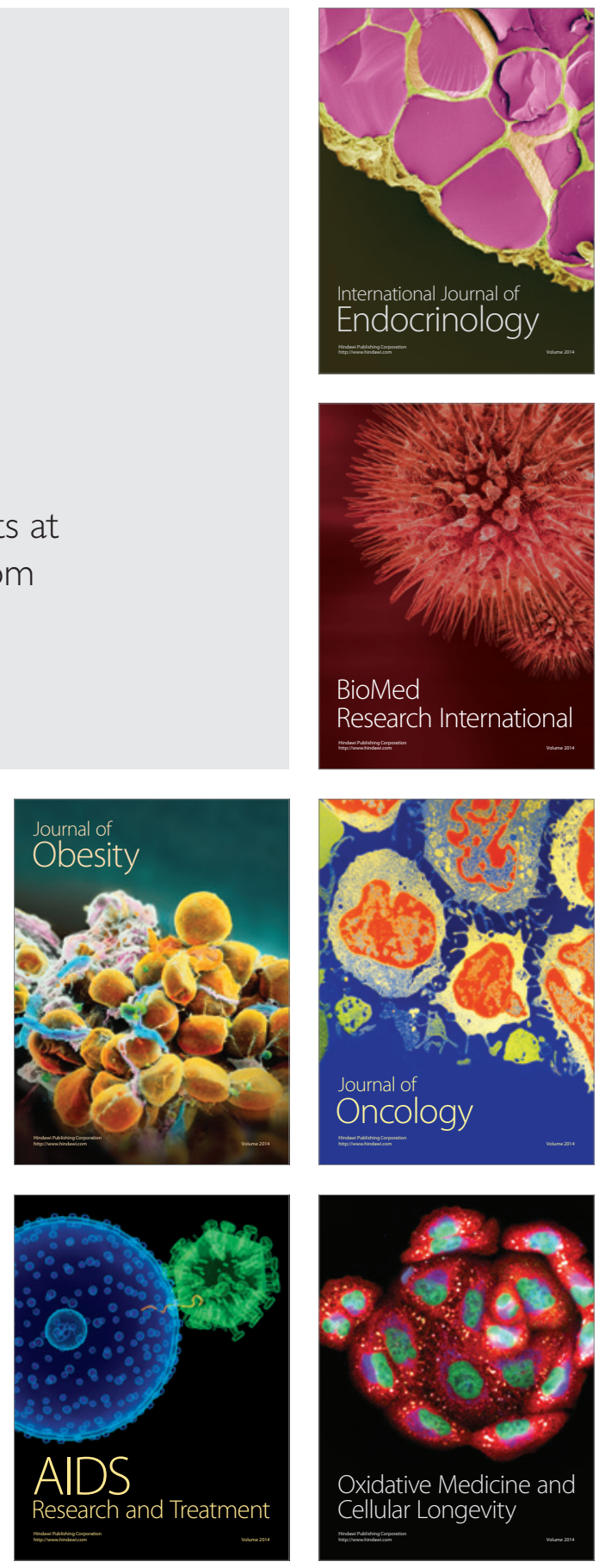